\title{
The Decarbonization of the Shipping Industry and the New Fuel Issue
}

\author{
Alexandros M. Goulielmos ${ }^{1,2}$ \\ ${ }^{1}$ University of Piraeus, Piraeus, Greece \\ ${ }^{2}$ Business College of Athens, Athens, Greece \\ Email: ag@unipi.gr,am.goulielmos@hotmail.com, agoulielmos@bca.edu.gr
}

How to cite this paper: Goulielmos, A. M. (2021). The Decarbonization of the Shipping Industry and the New Fuel Issue. Modern Economy, 12, 1999-2022.

https://doi.org/10.4236/me.2021.1212105

Received: November 3, 2021

Accepted: December 27, 2021

Published: December 30, 2021

Copyright $\odot 2021$ by author(s) and Scientific Research Publishing Inc. This work is licensed under the Creative Commons Attribution International License (CC BY 4.0).

http://creativecommons.org/licenses/by/4.0/

\begin{abstract}
The efforts of the international community to build the green ships of the future, and modify the present ones, by decarbonizing them, were described. These efforts depend on the joint effort of 7 major global enterprises: marine engine manufacturers, energy providers, marine fuel suppliers, shipyards, classification societies, ports and charterers. To date, 5 fuels have been suggested: LNG, biofuels, ammonia, methanol and hydrogen. Shipowners are happy using the heavy fuel oil (HFO), which they employed for the last 38 years. This was a result of efforts made by engine manufacturers and fuel providers (the seven major oil companies), due to the sudden increases in fuel oil prices in 1973 and 1979. Technology provided more efficient engines, and cheaper new fuel. In 2005, the IMO terminated shipowners' happiness by adopting Annex VI of the MARPOL 1973/1978 International Convention. Shipowners seek now the new fuel to have the following six properties: 1 ) cheap (as HFO), 2) safe, 3) compatible with the (new) engines, 4) available, 5) of high energy density, and 6) produced in adequate quantities. They most probably will get new fuel, but in the meantime, they have to build dearer, dual-fuel-ready ships, which comply with $\mathrm{NO}_{\mathrm{x}}$ Tier III regulations. Twenty-five projects are described, which attempted to decarbonize the planet, and shipping. The concept of increasing returns is reintroduced. Environment will improve by itself, we believe, during 2022 and thereafter, due to COVID-19 and the present energy crisis. Nations need to resort to Renewable sources of Energy immediately, and in any event, by 2050 . But will the energy crisis act as a brake on economic development?
\end{abstract}

\section{Keywords}

Shipping, Decarbonization, Shipowners, Fuels, Increasing Returns, Classification Societies, Shipyards, Energy Crisis 


\section{Introduction}

In the past, shipping, and other industries, considered that the sea is available free and capable of absorbing any kind and quantity of pollution ${ }^{1}$. Technical progress $^{2}$ resulted in tankers becoming larger and larger, in order to secure economies of scale.

Unfortunately, shipping caused a number of major tanker accidents: Torrey Canyon $^{3}$ (1967), Amoco Cadiz ${ }^{4}$ (1978), Exxon Valdez ${ }^{5}$ (1989), Braer ${ }^{6}$ (1993), Sea Empress $^{7}$ (1996), Erika ${ }^{8}$ (1999), and Prestige ${ }^{9}$ (2002). Could these have been avoided? Hindsight is excellent, but one must examine the causes of accidents if history's mistakes are not to be repeated. The study of marine accidents, over many years, taught us that an accident is the culmination of an entire chain of errors ${ }^{10}$.

The relevant legislation on air pollution adopted by $\mathrm{IMO}^{11}$ in 1997, and came into force 8 years later. This focused on the effects of ships' emissions on environment. It set limits (Appendix 1) on emissions of Sulphur and nitrogen oxides and $\mathrm{CO}_{2}$, released from ships' exhausts, and which have depleted the ozone layer ${ }^{12}$. Later, emissions of particulate matter ${ }^{13}$ were added.

Many people characterized the decarbonization of shipping as the most serious challenge ever faced by the industry. On $15^{\text {th }}$ July, 2011, the IMO adopted the mandatory EEDI ${ }^{14}$ (Energy Efficiency Design Index) for new ships (MARPOL Annex VI), and the SEEMP (Ship Energy Efficiency Management Plan) for all ships.

\footnotetext{
${ }^{1}$ A penalty fee for oil pollution from ships had to be established since the 1950s, to create a fund for the protection of the sea. The International Chamber of Shipping proposed something similar in October 2021.

${ }^{2}$ Goulielmos (2021)

${ }^{3}$ The grounding of this tanker deposited 100,000 tons of crude oil into the sea, off southwest England. ${ }^{4}$ She failed to enter the English Channel and grounded on the coast of Brittany, where she broke. This resulted in the 1978 MARPOL Protocol and the involvement of governments in shipping matters for the first time...

${ }^{5}$ Alaska. It led to Oil Pollution Act 1990 in USA. Shipowners dislike legislation passed by a single nation outside IMO.

${ }^{6}$ In the Shetland Islands.

${ }^{7}$ Near Milford Haven, UK.

${ }^{8} 31,000$ tons of oil poured into the Bay of Biscay on the Britany coast, France. She had 10\% less steel in her construction.

${ }^{9}$ Spain. 60,000 tons of oil spilled into the sea.

${ }^{10}$ In the Titanic disaster (1912), the initial cause was the binoculars missing from the bridge, which prevented the two officers on watch seeing the iceberg. The ship turned left to avoid the iceberg (wrong action); she touched the iceberg pushing it away. This caused the rivets to spring out of the hull, creating a leak in more than 4 departments. Icebergs are almost invisible during the night, and are more frequent further north, where ships sailed to gain time and reach New York faster. The ship ignored telegraphic warnings from other ships about icebergs. The fact that the telegraphy office was private also played a role.

${ }^{11}$ https://www.imo.org/.

${ }^{12}$ Ozone protects earth from sun's harmful rays.

${ }^{13}$ Volatized materials, during handling, and from turbines.

${ }^{14}$ https://www.imo.org/en/OurWork/Environment/Pages/GHG-Emissions.aspx, The IMO also introduced the EEXI (Efficiency Existing Ship Index) and CII (Carbon Intensity Indicator) to come into force by 2023.
} 
In 2018, IMO adopted ${ }^{15}$ the "Greenhouse Gases Emissions Strategy" to reduce GHG emissions by half relative to their 2008 levels. The goals were ambitious, requiring new ships to cut their carbon intensity by $40 \%$ by 2030 (relative to 2008). In 2021, IMO set a new target of cutting $1.5 \%$ off $\mathrm{CO}_{2}$ each year between 2023 and 2026. Shipping is responsible for an additional five causes of pollution, in addition to oil spills, normal emissions and GHGs (Figure 1).

Regulations in MARPOL 1973/1978 Annexes prevent most of the above. Biofouling ${ }^{16}$ including the impact of barnacles are pollutants due to ships being long idle, estimated to be responsible for at least 110 million tons extra carbon emissions p.a. This first became a problem during the 2009-2021 crises.

Some major companies, at the end of 2021, called for ships that will emit zero GHGs by 2050 , so long as this is clearly signaled as a dominant situation for ships by 2030 .

Moreover, the EU Commission announced its Green Agreement and package Fit for 55 -meaning ${ }^{17}$ to reduce carbon emissions by $55 \%$ by 2030 (from 1990 levels). This shortened the decarbonization time by 20 years, which is very ambitious. In addition, the EU proposed the extension of its Emissions Trading System $^{18}$ (ETS) to include shipping. This is a new climate plan, where EU ETS ${ }^{19}$ will cover about $90 \mathrm{~m}$. tons of $\mathrm{CO}_{2}$, which is expected to be emitted by ships.

In 2021, an energy crisis was caused by the increase in the price of natural gas, when the price quintupled. The energy sector is fundamental to all economies. The energy sector emits $75 \%$ of the $\mathrm{MtCO}_{2} \mathrm{e}$ in the EU-27. This implies a dependence on the natural gas of nations that had different political systems from EU. An easy solution for EU-27 is to depend on its own energy sources, including its schist industry.

A cleaner planet, and a cleaner shipping industry, will be the target of the world leaders who meet in Glasgow in November 2021, to discuss world climate.

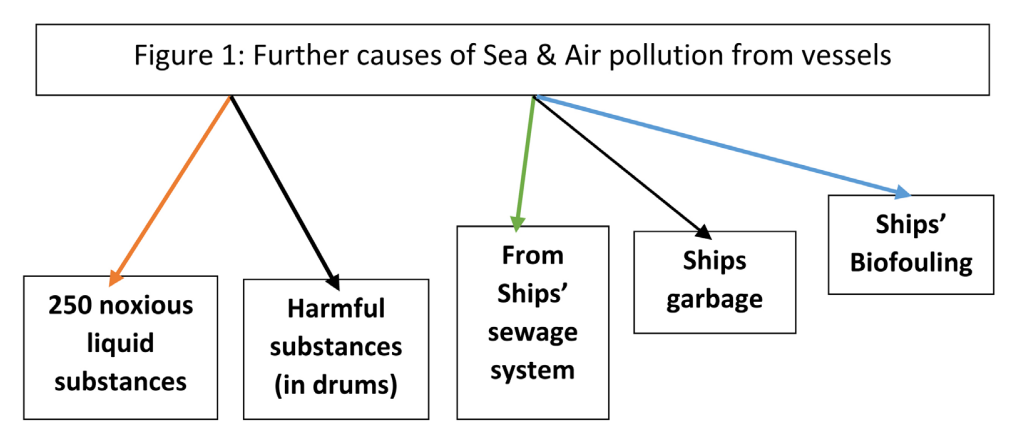

Figure 1. Further causes of sea \& air pollution from vessels. Source: inspired by Stopford (2009: p. 682).

\footnotetext{
${ }^{15}$ https://www.offshore-energy.biz/imo-members-agree-on-50-pct-ghg-emissions-cut.

${ }^{16}$ https://www.offshore-energy.biz/the-global-biofouling-challenge-calls-for-new-technology.

${ }^{17}$ Providing nearly $€ 72$ billion, between 2025-2032, for the climate. Near $€ 15 \mathrm{~b}$ will come from ETS revenue in 2021, plus an amount from energy taxes.

${ }^{18} \mathrm{http}: / /$ EUrevisesETStoincludeshippingsector.

${ }^{19}$ The right to emit carbon dioxide costs €60/ton now, meaning 6 times higher prices than 2013-2018. The verified $\mathrm{CO}_{2}$ emissions from the four dominant countries, in 2007, were: Germany 487 million tons, UK 257, Italy 226, Poland 210 (1180 m). The ETS system should be terminated, in our opinion.
} 
The world climate is positioned as an enemy, not a friend as it used to be, following the meetings in Kyoto (2005) and Paris (2015). 150 maritime leaders (the Global Maritime Forum- $\mathrm{GMF}^{20}$ ), at the end of 2021, demanded that governments set a target of zero GHGs emissions by 2050, providing incentives under the slogan: "Call to action for shipping decarbonization". This also played into the $\mathrm{COP} 26^{21}$.

Finally, one question has to be answered: Are the cities into which we bring children to live totally acceptable? (Figure 2)

In October 2021, The International Chamber of Shipping ${ }^{22}$ submitted a plan to $\mathrm{IMO}^{23}$, for additional measures to be taken by governments to achieve zero emissions ${ }^{24}$ by 2050. It is recognized that ships emit particulate matter, $\mathrm{NO}_{\mathrm{x}}, \mathrm{SO}_{\mathrm{x}}$ and $\mathrm{CO}_{2}$, which are considered co-responsible for the present revenge of the climate. Certain people argue that maritime industry has to show signs of effective decarbonization earlier, meaning by 2030 .

The importance of this research is due to a number of fundamental reasons: 1) the decarbonization of shipping/maritime industry will improve the global climate. 2) The ships-about 27,000-will have to install new engines burning the new-still unknown-green fuel. 3) This research reflects-in an objective way-the views of the shipowners. 4) It lists the advantages and disadvantages of each fuel, but most important of all is that in economies "increasing returns" apply and thus one fuel will prevail... This has the corollary that the various efforts-where only 25 mentioned here-had (have) to be coordinated as at the end one fuel will be used, and hundreds of millions of \$ spent already will have no real response... The limitation is that our theory cannot indicate which fuel

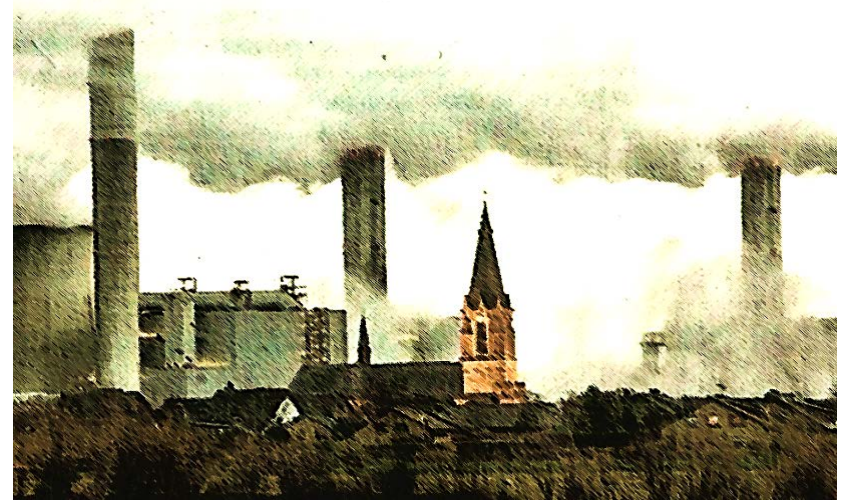

Figure 2. The cities parents deliver to their children. Source: modified from that release by Reuters (2021).

\footnotetext{
${ }^{20}$ The members are shipping companies, energy providers, ports, charterers, banks, shipyards, classification societies, canal authorities, car manufacturers and owners of the infrastructure.

${ }^{21}$ Scotland is going to host the $26^{\text {th }} \mathrm{UN}$ conference on climate change, in Glasgow, between $31 / 10 / 2021$ and $12 / 11 / 2021$, under the acronym COP26.

${ }^{22} \mathrm{ICS}$ proposed a compulsory R\&D fund of $\$ 5 \mathrm{~b}$. to develop technologies of zero emissions, together with a fee on ships for a faster transition to a more expensive fuel, providing zero carbon balance. ${ }^{23}$ IMO's opinion is a key.

${ }^{24}$ The forthcoming conference, "Shaping the Future of Shipping", takes place in Glasgow parallel to COP26.
} 
of the 5 on the agenda will be. The further contribution of this research is really that a number of complex issues are discussed for the first time like decarbonization, the new fuels, maritime and general environmental issues.

\section{Aim and Structure of the Paper}

The paper analyzed the global, and maritime, efforts, to discover one or more green fuels, which will replace, wholly or in part, HFO. It is believed that this target can be achieved if accompanied by certain limits on ships' GHGs emissions, as set by the IMO since 2005 .

The paper is structured in nine parts, after literature review. Part I presents the 25 current projects to decarbonize the planet and shipping. Part II deals with the new ideal role for classification societies and shipyards. Part III deals with the dilemma: climate as a friend or economic growth as an enemy. Part IV deals with the efforts of maritime community to "discipline" ships to avoid oil pollution at sea, on the principle of reactivity. Part V deals with various issues relating to oil pollution at sea. Part VI deals with the history of using fuel oil by ships (the HFO case study below). Part VII deals with the history of marine fuels. Part VIII deals with the fuels that are candidates for future: their advantages and disadvantages. Part IX deals with the impact of the current energy crisis. Finally, the paper concludes.

\section{Literature Review}

Lorange (2009: pp. 178-181) argued that, twelve years ago, the large shipping companies were prepared to reduce fuel consumption and diminish air pollution, by adopting one or more mitigating actions, as shown in Figure 3.

Steady steaming provided fuel savings and fins added to rudders improved hull design. The propeller system, and the anti-fouling of hulls, also improved ship's performance, using friction-reduced paints. Electronic fuel injection in diesel engines created fuel-savings. The $\mathrm{CO}_{2}$ emissions per unit load of ships were very low-from 1 to 11 units-compared to a maximum of 398 for airplanes, and 6 for railways (due to Lorange, 2009: p. 180). Moreover, $\mathrm{NO}_{\mathrm{x}}$ emissions were reduced by using a catalytic converter, which transforms urea using air and water. Seawater was also used to clean Sulphur from bunker fuel (the

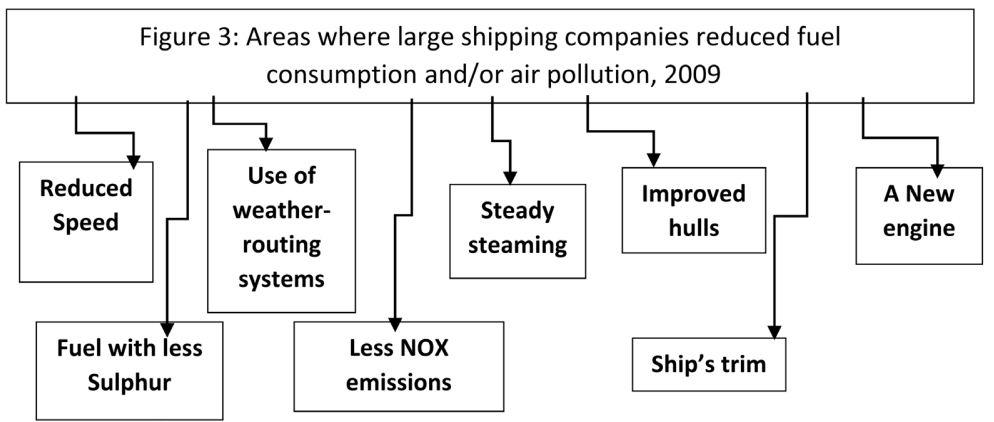

Figure 3. Areas where large shipping companies reduced fuel consumption and/or air pollution, 2009. Source: inspired by Lorange (2009). 
snubbing technology).

A scrubber is also recommended in recent years to prevent air pollution, but it is quite expensive, with a current price of nearly $\$ 1 \mathrm{~m}$. The ship's trim can be improved to reduce fuel consumption if the vessel has optimum speed. Moreover, the bow and stern are designed to be at a specific depth in the water. To achieve this, the dynamic trimming assistant-DTA—can be used. Optimal routing can be obtained from special providers, minimizing the distances covered by the vessel.

As shown, large shipping companies tried to economize on fuel consumption in many ways. Large Greek companies adopted policies to reduce fuel cost during the deep and prolonged shipping crisis (1981-1987). This had to be a continuous effort to reduce fuel consumption, whether or not it contributes to decarbonization. Between them, the 8 methods listed above (Figure 3) are expected to reduce fuel consumption by $40 \%$ !

This paper innovated because it placed the economies of the increased returns into the decarbonization effort of the maritime industry, along with energy crisis. It avoided the few lengthy technical analyses existed, incomprehensible for many of the maritime literature readers. The non-technical, and economic, research is rare as far as the new fuel is concerned. In addition, surfing in internet, we listed 25 important projects with several million \$ in investing, from powerful global players in fuel production and supply, engine manufacturing, users and ports, etc.

This paper is proud for its suggestions to: ship classification societies, global shipyards, machines manufacturing, etc., all to adopt AI. Towards societies with a new "speed limits" policy, an insight into growth \& development models so that the climate to contribute to growth! A dilemma for further research... where environmentalists accuse economists and economists accuse environmentalists! Nature revenge economists. A great amount of information found in internet communications from shipping information centers is mentioned.

\section{Part I: 25 Projects to Decarbonize the Planet and the Shipping Industry}

The current level of mobilization, in the form of joint ventures among various companies, to decarbonize the planet and shipping is impressive (Table 1). The system might work more effectively, however, if the UN and IMO, each, established, an international body to coordinate and monitor these various projects. In the absence of such coordination, the proposed fuel and engine technologies will be competing. A better approach would be to combine international forces, at least among allies. But before focusing on shipping, an attack on emissions is needed reducing $\mathrm{CO}_{2}$ emissions from air-travel, agriculture ${ }^{25}$ and certain uses of land.

\footnotetext{
${ }^{25}$ Greeks established a startup, the "Better Origin", producing food for animals (chickens to start with) from insects (black soldier flies), in an automated laboratory. This project saved emissions of $\mathrm{CO}_{2}$ equivalent to 565 tons/year. The technology mimics nature, in which nothing is wasted, not even residuals of food (931 million tons in 2019, 61\% from households).
} 
Table 1. Shipping decarbonization (= zero emissions) 25 projects (end 2021).

\begin{tabular}{|c|c|c|c|}
\hline $\begin{array}{c}\text { Partner Companies/ } \\
\text { Organizations/Countries }\end{array}$ & Project & Companies & Project \\
\hline $\begin{array}{l}\text { Port of } \\
\text { Singapore \& IMO }\end{array}$ & NextGEN $^{26}$ portal & $\mathrm{NYK}^{27} \& \mathrm{BP}$ & Net-zero GHG emissions by 2050 \\
\hline S Arabia \& IMO & $\begin{array}{l}\$ 1 \mathrm{~m} \text {. to tackle biofouling, } \\
\text { eliminate marine plastic } \\
\text { litter and cut ships emissions }\end{array}$ & $\begin{array}{l}\text { Uniper \& Port } \\
\text { of Rotterdam }\end{array}$ & $\begin{array}{l}\text { Production of green hydrogen }{ }^{28} \text { by } \\
2025 \text { from } 100 \mathrm{MW} \text { to } 500 \mathrm{MW}\end{array}$ \\
\hline $\begin{array}{l}\text { Port of Immingham, } \\
\text { Toyota, Uniper, } \\
\text { Siemens \& Association } \\
\text { of British Ports }\end{array}$ & Use of hydrogen ${ }^{29}(\$ 32 \mathrm{~m})$ & $\begin{array}{l}\text { Maersk, MAN } \\
\text { (engines) \& } \\
\text { Prometheus Fuels } \\
\text { (a cost-efficient, } \\
\text { carbon-neutral, } \\
\text { eFuel }^{30} \text { ) }\end{array}$ & $\begin{array}{l}\text { Build } 8 \text { methanol-powered contai- } \\
\text { nerships by } 2024 \text {; liquefied metha- } \\
\text { nol can be produced from biomass } \\
\text { (LBG) }\end{array}$ \\
\hline $\begin{array}{l}\text { MAN Energy \& } \\
\text { DP World }\end{array}$ & $\begin{array}{l}\text { World's 1st synthetic natural gas } \\
\text { (SNG); it powers a containership } \\
\text { supplied with } 20 \mathrm{t} \text {, in Germany }\end{array}$ & $\begin{array}{l}\text { Northern Lights } \\
\text { (a Shell joint venture), } \\
\text { Equinor \& } \\
\text { Total Energies }\end{array}$ & $\begin{array}{l}\text { Two LNG-powered, wind } \\
\text { assisted, liquid } \mathrm{CO}_{2} \text { carriers } \\
\text { ordered, in Dalian, } \\
\text { with air lubrication technology }\end{array}$ \\
\hline $\begin{array}{l}\text { Euronav, Hyundai, } \\
\text { Lloyd's } \\
\text { Register \& DNV }\end{array}$ & $\begin{array}{l}\text { B30 biofuel }{ }^{31} \text { blend }(360 \mathrm{MT}) \text { for } \\
\text { vessel Statia }(150,205 \mathrm{dwt}) \\
\text { used in the port of Rotterdam } \\
\text { a joint development project } \\
\text { for ammonia-fitted tankers }\end{array}$ & $\begin{array}{l}\text { A classification } \\
\text { society granted } \\
\text { approval-in-principle } \\
\text { (AiP) to a S } \\
\text { Korean shipbuilder }\end{array}$ & $\begin{array}{l}\text { To design and develop an } \\
\text { ammonia } \\
\text { carrier }{ }^{33} \text {-ammonia-fuelled } \\
\text { propulsion, for very large gas } \\
\text { carriers, with zero carbon } \\
\text { emissions }\end{array}$ \\
\hline Rolls-Royce & $\begin{array}{l}\text { Tested a 250-kilowatt } \\
\text { demonstrator using hydrogen } \\
\text { fuel cells for zero carbon, with } \\
\text { a sustainable power supply }\end{array}$ & Chevron & $\begin{array}{l}\text { Plans to produce renewable natural } \\
\text { gas of } 40,000 \text { MMBitu/day to } \\
\text { supply a network of stations } \\
\text { serving heavy duty transport } \\
\text { customers }\end{array}$ \\
\hline Marinvest $\mathrm{AB}^{34}$ & $\begin{array}{l}\text { Delivered }{ }^{35} \text { two dual-fuel methanol } \\
\text { carriers }(\sim 50,000 \mathrm{dwt}) \text { in } 2016 \text {, } \\
\text { three more added and plans for a } \\
\text { further } 8 \text {; IMO Tier III compliant; } \\
\text { chartered to Waterfront Shipping, } \\
\text { a subsidiary of Methanex Corp. }\left(^{*}\right)\end{array}$ & $\begin{array}{l}\text { Greeks are } \\
\text { preparing }\end{array}$ & To produce methanol \\
\hline
\end{tabular}

${ }^{26}$ It manages 140 plus projects with 500 partners and 13 fuel types in Africa, Asia, Caribbean, Latin America, Middle East and the Pacific islands on line.

${ }^{27}$ https://www.offshore-energy.biz/bp-nyk-line-to-work-together-on-shipping-decarbinization/.

${ }^{28} \mathrm{https} / / / \mathrm{www}$. Rotterdam.com/en/news-and-press-releases/uniper-and-port-rotterdam-authority-sta rt-feasibility-study-green-hydrogen.

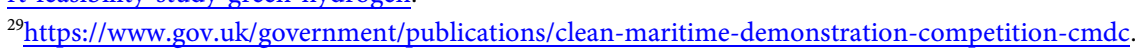

${ }^{30}$ Efuels are: biodiesel, alcohols, lignite-enhanced alcohol and ammonia (known as electro-fuels) plus fuels from waste.

${ }^{31}$ Consisting of $30 \%$ biofuel mixed with $70 \%$ VLSFO fuel.

${ }^{32}$ https://www.portofrotterdam.com/en/port-future/energy-transition/incentive-scheme-climate-frie ndly-shipping.

${ }^{33} 227 \mathrm{~m}$ long, $36.6 \mathrm{~m}$ wide, $23.6 \mathrm{~m}$ deep, equipped with 4 prismatic-type cargo tanks of 91,000 c.m. IEA predicted that ammonia will account for around 45\% of global energy demand by 2050 .

${ }^{34}$ All shares acquired by MSEA group, Arkview Capital, and Scorpio tankers (a joint venture).

${ }^{35}$ https://www.offshore-energy.biz/two-ocean-goig-methanol-fueled-newbuilds-join-waterfront-fleet/ 


\section{Continued}

\section{MAN Energy}

Solutions

Motor Oil (coordinator), the Greek State Gas

Production

Company \& 8 others
CEA (machinery \& plant manufacturer)

Fortescue

IMC Ventures, Signal Ventures, Mitsui OSK Lines \& MOL PLUS
A commercially viable, ammonia-powered marine engine by 2024, destined for large ocean-going containerships

The Greek shipowner TEN (Tsakos)

Chevron

Chevron,
Wartsila \&
Caterpillar

Reduce emissions with in-house solutions; ammonia an option ${ }^{* * *}$ )

To convert existing fleet of $8 \times$ $260,000 \mathrm{dwt}$, \& new ones, to run on green ammonia by 2040

Investing in startup companies with innovative technologies for decarbonization (and digital transformation) of ocean shipping/logistics, spending near \$23 million

GoodFuels \&

Unifeeder

International

Maritime

confirmed by

IRENA $^{39}$
Ordered 6 LNG-powered tankers from a S Korean shipyard ${ }^{36}: 4$ Aframax \& 2 optional LR2 petroleum product carriers, at $\$ 417$ million by 2022 ; vessels to be fitted with dual-fuel engines (LNG \& HFO)

A clean-energy plan of $\$ 10 \mathrm{~b}$. by 2028 , to increase renewable energy production (\& hydrogen) to $150,000 \mathrm{t}$ p.a. for industrial power, heavy transport users, \& up to 100,000 barrels/day for renewable diesel \& sustainable aviation fuel

Caterpillar develops a hydrogen demo for transport, for stationary power \& prime power, including trains

The White Dragon ${ }^{37}$, Green HiPo \& CHP

Hydrogen stored in innovative tanks, electrolyte production \& fuel cells

Bunkering (bio-bunkering) of sustainable marine fuel ${ }^{38}$ (in Port of Rotterdam); the fuel dropped-in existing engines \& produced by certified feedstocks (waste or residuals) $\left(^{* * * *}\right.$ )

Shipping Company;
Green hydrogen \& advanced biofuels to cut $\mathrm{CO}_{2}$ emissions ${ }^{40}$ by $80 \%$ by 2050 ; \& e-methanol \& e-ammonia $(* * * * *)$

$\left.{ }^{*}\right)$ Methanol reduces emissions by $\left.95 \% .{ }^{* *}\right)$ Built 2000 fuel cells \& 600 electrolytes $\left({ }^{* *}\right)$ At the Ship Efficiency Conference, Hamburg, 27-28/09/2021). (****) This kills two birds with one stone by using waste and food residuals. (*****) About $183 \mathrm{~m}$. tons of ammonia are needed for shipping now, and this quantity is being produced. IRENA argued that a fuel's cost of production and availability will determine its selection.

\footnotetext{
${ }^{36}$ The shipyard developed an LNG-powered vessel in 2018.

${ }^{37}$ This is a project of $€ 8 \mathrm{~b}$. to produce hydrogen by electrolysis using solar energy. The hydrogen will be transferred by TAP pipeline.

${ }^{38}$ Feedstock and marine gasoil (MGO) (https://www.offshore-energy.biz/goodfuels-markets-it-easy-to-go-green/).

${ }^{39}$ International Renewable Energy Agency (https://www.irena.org/publications/2021/Oct/A-Pathway-to-Decarbonise-the-Shipping-Sector-by-2 050).

${ }^{40}$ There is a difference between zero $\mathrm{CO}_{2}$ emissions and net zero. The latter needs $100 \%$ renewable energy derived fuels.
} 
In summary, this impressive array of projects, involving many companies, is already in place to decarbonize the planet and shipping. This goal can be achieved by international collaborative effort, we believe.

\section{Part II: The New Ideal Role for Classification Societies and Shipyards}

One can imagine an ideal situation where the R\&D departments of large shipbuilding companies (Bruce \& Garrard, 1999), and the classification societies, and large shipping companies come together to use artificial intelligence ${ }^{41}-\mathrm{AI}-$ to make smart on-board machines. Such machines would not need pre-training, and they can be self-taught (Metz, 2021), capable of mimicking the human brain. A smart main engine could ask for a spare part, or for regular maintenance. Or an engine, recognizing that it is overloaded, could bring an auxiliary engine on-line.

One can imagine an intelligent radar to indicate the most economic route, and also to show the weather conditions seven days ahead; this is now possible. The captain has the best information about the condition of the ship, and if knowledge of wind speeds and waves can be shown on smart radar, the captain would be in a position to choose to seek a port of refuge, rather than risking the ship, the cargo and the crew (Goulielmos \& Gatzoli, 2012).

The future ideal shipping industry will benefit from machine learning, deep learning, and neural networks ${ }^{42}$. The first neural network, built in 1958, the Perceptron, is very useful for shipping, even today, as it can recognize printed letters, handwritten words, oral instructions, human faces, and translate languages. A network can be expanded into the fascinating area of connectionism. China has announced that it will create an ideal shipbuilding industry by 2030, using AI to ensure that all machines and engines on board are smart.

\section{Part III: The Climate as Friend and Economic Growth as Enemy}

Science faces a big dilemma: Is the climate a friend or is economic growth the enemy? (Taliapetra et al., 2021). Theories of growth embody certain contradictions. Neo-classicals believe that the economy is inherently stable and tends to full employment. Keynesians argue that the economy is unstable and the errors of the Classicals and Neo-classicals must be corrected. The Keynesian and Neo-Keynesian school is best represented by the Harrod-Domar growth model for a single sector. This model posits a constant capital output ratio, $V$, which is to be achieved, and a constant long-term real rate of interest, $R$, with savings, as a constant percentage of real income; $S$. Labor increases by $n$, accompanied by technical progress ${ }^{43}, t$.

\footnotetext{
${ }^{41} 1956$ at Dartmouth College.

${ }^{42} 1989$.

${ }^{43}$ Technical progress is labor-saving.
} 
In this model, savings, are the key element, and equal the required investment to achieve growth. $S / V$ must change at $n+t$. The expected growth rate is defined as $\mathrm{d} Y / \mathrm{d} t$, and the economy will balance if $S / V=\mathrm{d} Y / \mathrm{d} t$. This means savings must be equal to the resources required by investment to achieve the expected growth rate. While Keynesian consumption is based on a powerful human law, investment is too. Keynes hides this investment in "animal spirits" (Keynes, 1936: p. 161). Human spirits-a better term-represent the "spontaneous human optimism", the "inclination for one businessman to do something positive", and the "spontaneous human urge to act". Human psychology was the foundation of Keynes' theoretical construction (Goulielmos, 2018).

The more economic laws one establishes, the more similar economics becomes to mathematics and physics! Economists have always envied physics and mathematics for their positiveness. Keynes understood the great importance of investment, over the passive role of consumption, and devoted roughly half the pages in his 1936 book to investment. Keynes clearly saw that investment is not an automatic process, based on the availability of funds to finance investment projects. The human spirits are a necessary, but not a sufficient, condition for enterprisers-as Keynes called business-men. Two further conditions were needed: 1) A sufficient degree of confidence about the marginal efficiency of the investment in an uncertain future; 2) The level of the deflated rate of interest, which has to be paid, must be less than the rate of return on the investment in the project over its whole life, which may be as long as 20 years.

During an economic crisis, although interest rates are low, confidence is absent. If a crisis is global, neither tourism nor exports can help. Governments have to be enterprisers, or at least good economists, and they must realize investment, as allowed by savings, which enterprises cannot, despite their spirits. Taliapetra et al. (2021), argued that to defeat the climatic enemy, the planet has to be decarbonized, where $80 \%$ of global energy comes from fossil fuels, to maintain the global rise in temperature below 1.5 degrees $C$ from the level of the global pre-industrial period.

Though certain targets sound long-term, they are not; they are urgent if we are to prevent fires, floods and the very hot summers. Volcanoes, like that in La Palma, Spain, cannot be controlled. The cost of decarbonizing the planet and shipping is an important consideration, but there is no clear answer. The International Energy Agency (IEA) argues that governments should spend $4.5 \%$ of their GDP, which would mean an $80 \%$ increase. The global GDP in 2020 was roughly $\$ 84$ tr., so global investment of about $\$ 3.8$ tr. will be required. Greece, for example, will have to spend nearly $\$ 11 \mathrm{~b}$. This means that it would be cheaper for the Greek government to forget about climate. A Greek bank consultant argued (Sunday Press, 10/10/2021) that Greece needs $€ 50 \mathrm{~b}$. in investments, or more than $20 \%$ of its 2017 GDP, to achieve decarbonization.

All hopes to save the planet and shipping, after governments fail to take the necessary action, rest on technology, such as hydrogen produced from renewable 
sources of energy, or the increased storage capacity of batteries. There are also technologies that catch or absorb $\mathrm{CO}_{2}$ at source. These are very costly, technologies at the moment.

\section{Part IV: The Efforts of the Maritime Community to Discipline Ships to Avoid Oil Pollution at Sea on the Principle of Reactivity}

Sea pollution preoccupied an international conference for the first time in 1952 in London. This resulted in the 1954 convention for the prevention of pollution of the sea by oil (OIL POL 1954) (Farthing \& Brownrigg, 1997). The focus of the conference was that tankers used to discharge their ballast water, containing residual oil, into sea, just outside loading ports. The convention made provision for "reception facilities", but these were for dry cargo ships, and not for tankers. However, the convention merely moved the problem, because it allowed ships to discharge oily ballast water 50 miles from nearest land, even though the sea is connected into one and does not have separate zones.

The shipping community has introduced a number of important conventions, like MARPOL in 1973 and SOLAS in 1974, in almost all cases after a serious marine accident. Public opinion and mass media played a role by exerting pressure on politicians, and those politicians who were ignorant of sipping passed legislation. Imagination is not the strong card of the shipping industry. In the past, captains had exclusive responsibility for a marine accident, until the ISM Code was adopted in $1994^{44}$. Captains are still responsible today if the company's management onshore has met all conditions for safe management.

It took 21 years, from 1952, for the shipping community to adopt the 1973 MARPOL convention, which had wider coverage. Between 1952 and 1973 community failed to adopt a holistic approach that combined the regulations for sea pollution with those for land-generated waste. The 1973 MARPOL Convention established, in 1978, important modifications, the two most important of which were segregated ballast tanks $(\mathrm{SBT})^{45}$ and crude oil washing $(\mathrm{COW})^{46}$.

A number of factors have inhibited more rapid legislation. Economies of scale ${ }^{47}$ led to the introduction of $\mathrm{VLCC}^{48} \mathrm{~s}$ and $\mathrm{ULCC}^{49} \mathrm{~s}$, with a corresponding greater potential for pollution. The introduction of double-hull tankers appeared to be considerably delayed, until 1993. The USA acted unilaterally to legislate the

\footnotetext{
${ }^{44}$ Adopted in 1994; in 1998 became mandatory for tankers \& bulk carriers; in 2001 for general cargo ships. Amended/revised 5 times (in 2002, 2006, 2009, 2010 \& 2015).

${ }^{45}$ The tanks for cargo, separated from those for ballast water (1978 MARPOL Protocol (02/10/1983)).

${ }^{46}$ The MARPOL 1978 protocol, required also a COW in new crude carriers of, or $>20,000 \mathrm{dwt}$ and in existing tankers of, or $>40,000 \mathrm{dwt}$, which had to have alternatively SBT. The COW has also an IGS (inert gas system). In COW part of the cargo is circulated via the fixed tank cleaning equipment to remove waxy asphaltic deposits in the tank.

${ }^{47}$ We have rather to blame naval architects for not taking into account the probability-however small-of sea pollution by those giant tankers (VLCCs \& ULCCs).

${ }^{48}$ Initials for the very large crude carrier-a tanker carrying $2 \mathrm{~m}$ barrels of oil!

${ }^{49}$ Initials for the ultra large crude carrier-tanker carrying more than 2 million barrels of crude oil.
} 
Oil Pollution $\mathrm{Act}^{50}$ in 1990. Shipowners allowed politicians to limit their actions in regard of sea pollution, rather than acting themselves. Shipowners suffered two serious marine accidents, M/T Erika in 1999 and M/T Prestige in 2002, in EU sea areas, which turned the EU against them. (6) Port states did not provide ports of refuge for damaged/distressed ships. And shipowners allowed the establishment of the very useful Port State Police/control ${ }^{51}$.

The IMO was responsive rather than proactive, and governments were the same. They concentrated on regulations covering how ships are built, by co-approving the regulations of the classification societies. They would have done better to check the shipyards for how they built ships ${ }^{52}$, and boost technical progress, with the aim of eliminating marine accidents. Overall, the shipping industry is reactive $e^{53}$, and the IMO is reactive $\mathrm{s}^{54}$.

\section{Part V: Further Issues on Oil Pollution at Sea}

1) Patterns in oil pollution at sea

Governments and IMO would be better advised to read certain publications (Goulielmos et al., 2002) supporting the idea that accidents, whether on highways or at sea, are not random. If accidents are not random, governments were either co-responsible or blind. The first task is to look at fatal accident statistics. If one asks why certain specific stretches of specific highways have accident rates that are 10 times the average, the government will most probably answer that this is random. Citizens, however, characterize these points as accident black spots. If marine accidents are random, then ships are forgiven. But if accidents are not just bad luck, further analysis is needed, and there has to be an explanation of why most marine accidents occur in the China Sea and/or the English Channel.

2) The human factor in marine accidents

There is an argument that the great majority $(60 \%-80 \%)$ of marine accidents are due to human error. But a human error is defined as an action or omission that results in a marine accident.

3) The tacit acceptance procedure

Although IMO's Conventions are often adopted in the immediate aftermath of a serious marine accident, they come into force many years later. This is a

${ }^{50}$ This act set stringent regulations and liabilities for tankers trading exclusively in USA national waters.

${ }^{51}$ This is a good paradigm shift.

${ }^{52}$ Chinese shipyards are now leading in orders.

${ }^{53}$ The adoption of the 1st SOLAS, (initials of "save our lives at sea"), convention due to $1^{\text {st }}$ World War delayed \& adopted in 1925.

${ }^{54}$ International maritime organization-IMO: a UN agency responsible for maritime safety etc. In operation since 1958 (as IMCO)/and since 1982 (as IMO), with 5 committees, of more than 166 member states and more than 300 staff (London). IMO's 16 main conventions are considered very important. Important is also chapter IX “on safe management (ISM Code) of ships”, a kind of management "quality standard" like those of the ISO. The code considered necessary after the 1987 marine accident, in Belgium, involving the F/B Herald of Free Enterprise (Goulielmos \& Goulielmos, 2005). 
mistake, which the IMO partly corrected in 1973-1974, by deciding if a convention had to be put into force at once. This is the tacit acceptance procedure ${ }^{55}$, and it would have been better if all conventions came into force immediately on adoption, and in any event soon after the accident that has led to them.

4) The cost of vessels' legal obsolescence

Many conventions, if not all, require a ship to comply with new requirements at an additional cost or to be scrapped ${ }^{56}$. Our proposal is that such legal obsolescence should be considered a cost that IMO's nations should pay. To minimize this cost, a prior responsibility has to be placed by Governments on their classification societies, with a view to pressing them to build ships that avoid pollution. Governments should also share obsolescence costs. The wisdom obtained from over 75 years of marine accidents is that we need better classification societies that can foresee trouble, and know what to do before the event.

Legal obsolescence is unfair, because it is effectively retrospective, and penalizes shipowners for errors that were not illegal when their ships were built. This makes the ship-owning profession quite uncertain. If a ship is built according to a good classification society (in IACS), and in a conscientious shipyard, she should be allowed to work until her scrapping.

If governments in the IMO wish ships to be "withdrawn" from the market, before their "natural death", so that to protect the environment, they should pay. Shipyards should also contribute and pay part of ships' market value (less ships' scrap value). Ships that are constructed legally obsolete will be rather cheap. Shipowners will be happy and fairly treated, and the "green" international community will be also happy. Governments, classification societies and shipyards will not, but this obligation to pay will make them more... careful.

5) The end of oil spills at sea?

Dealing with GHGs one may get the impression that the planet and shipping have finished with oil spills, but an oil spill occurred recently in Southern California that resulted in 126,000 gallons of oil being spilled into the Pacific Ocean, from the shore.

\section{Part VI: The History of Fuel Oil Used by Ships (The of HFO Case-Study)}

Shipping economists (Stopford, 2009: p. 233) argued that fuel oil is the single most important item among voyage costs, accounting for $47 \%$ in 2009 , and $50 \%$ in 2021, of the total voyage costs. The shipping industry is cost dependent, and not price-determining, like other industries (monopolies, monopolistic competitions, oligopolies). Shipping companies cannot fix their prices at the level they wish. Demand and supply set prices.

Between 1974 and 1985, fuel prices increased by 950\% (Figure 4).

As shown, the fuel cost increased many times between 1974 and 1979, known as the years of the energy crises, due to specific historical events which took

${ }^{55}$ Marine study (internet site).

${ }^{56}$ To have a scrubber, a double hull, to comply with ISM code. 


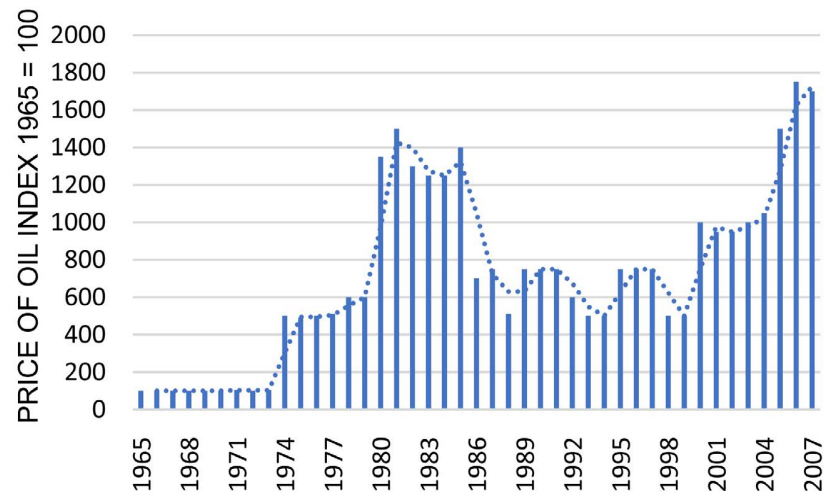

Figure 4. Fuel cost index, 1965-2007. Source: data from Stopford (2009: p. 226).

place in Middle East. Between 1974 and 1985, when fuel costs accounted for 34\% of total ship costs, resulted in investments ${ }^{57}$ in designing more fuel-efficient ships and operating in ways to reduce bunker consumption. This sounds familiar today, as the problem has re-appeared, and shipowners are reacting.

The intensive effort to reduce ships' fuel consumption was not made in the light of the long view, as it should have been, but on the basis of the contemporary oil price. The efforts continued until 1986, when oil prices fell. But the problem returned between 2000 and 2008, and again in August, 2021. The industry was reactive again. In all fuel oil crises, shipowners focus simply on reducing fuel consumption. Now, they try also to motivate governments to solve this new fuel problem. Fortunately, engine manufacturers, among others, have taken the initiatives. Powerful shipowners naturally believe that decarbonization requires a zero-carbon fuel, and also a new engine. The shipping industry, however, is not prepared to carry any costs, judging from Greek shipowners. Shipowners, at the moment, order ships on two principles: dual-fuel ready ${ }^{58}$ and $\mathrm{NO}_{\mathrm{x}}$ Tier $\mathrm{III}^{59}$, and pay a higher price.

Figure 5 shows the factors that determine a ship's fuel consumption.

As shown, the reduction in fuel consumption can be achieved in at least 10 ways. A ship's hull ${ }^{60}$ (area/surface) in touch with the sea has to be reduced,

\footnotetext{
${ }^{57}$ Progressive nations devote a large percentage of their GDP to applied research, in special laboratories, universities, and research centers. Progress was made in processing iron, and especially steel. The use of lighter, but equally strong, steel, was a great leap forward for economies of scale. This coupled with a better welding to fasten steel plates together, and robotics were added. Shipbuilding nations should produce a new blend of steel and become global champions in building ships. Steel prices, in September 2021 , went up to $\$ 1800 /$ ton from $\$ 500$. Scrap prices went-up to $\$ 450 /$ ton. Ship hulls from plastic, aluminum, glass, titanium or other materials used in space technology, are not used yet to build large ships... The new materials, together with AI, must focus on shipbuilding, to build larger, cheaper, stronger, smarter ships.

${ }^{58}$ Engines use a mixture of 2 different fuels (e.g., natural gas \& diesel) now.

${ }^{59}$ Standards required in ECAs, since 2016. This is an IMO regulation to be in force for all vessels above $24 \mathrm{~m}$, with a combined propulsion power of more than $750 \mathrm{~kW}$, and/or a generator engine above $129 \mathrm{~b}$. kW, which laid keel after 01/01/2021. The regulation sets NOx emission limitations in NECAs-nitrogen emission control areas-in North America, US Caribbean, Baltic \& North Sea. IMO Tier IV certification is also required for engine replacement (Source: MarQuip, in internet).

${ }^{60} \mathrm{~A}$ ship's bottom and its condition are also important. A reduction in hull roughness from $300 \mathrm{mi}-$ crometers to 50 , saves $13 \%$ of the fuel cost.
} 


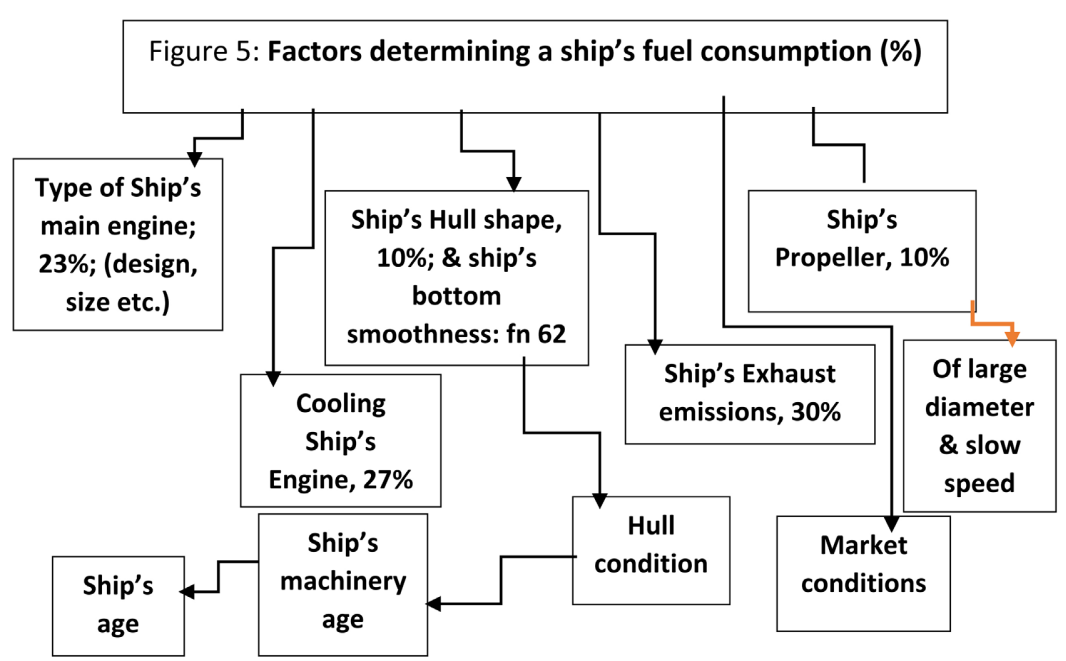

Figure 5. Factors determining a ship's fuel consumption (\%). Source: inspired by Stopford (2009: p. 233).

reducing friction (depending on ship's design ${ }^{61}$ ). The propeller is a science of its own. The cooling of the main engine has to be achieved using less energy. Exhaust emissions are used to heat the ship's water. The size (volume) of the ship engine must be reduced to free space for cargo-something that is rarely mentioned in theory. Engines should be small, operate at low revolutions and run-on cheap fuel.

Newer ships can be more economical, if they can be bought at a low price, and newer machinery, which normally is more efficient. All investment must obey one economic rule: the additional cost must be lower than the additional income from action. This means that market conditions are a key-element, and are often overlooked by the theory.

As Figure 5 shows, $57 \%$ of energy $(30 \%+27 \%)$ is used for two purposes, neither of which is moving the vessel! For example, a Panamax bulk carrier of 1990-2000 vintage, with a speed of 14 knots, consumes 30-tons/day in fuel oil, meaning fuel efficiency in moving her forward. Only $23 \%$ of the total energy is used to move the ship forward. This means a partial failure ${ }^{62}$ of ships' engine manufacturers. Economies in fuel consumption, achieved after 1980, accounted for 10 tons per day, or 25\%, other things being equal; but efforts should have been continued for more fuel-saving main engines.

Apart from the technical and mechanical factors in fuel consumption, the care with which the ship is operated also has a role. The fuel consumed when the ship is off-hire has to be under strict control, and slow steaming is always an option for Captains. High speed is less important for tankers and bulk carriers, than for containerships ${ }^{63}$. There are shipping companies who have already adopted all possible ways in reducing electricity consumption on board using LED technol-

${ }^{61}$ These ideas applied in Catamarans, as shown in Appendix 3.

${ }^{62}$ The "diesel internal combustion engine" was a great invention in saving energy in 1940s.

${ }^{63}$ It is remarkable what savings in fuel consumption were achieved by containerships during last economic crisis (2009-2018) by slow steaming. But there were great gains for the environment, too. 
ogy.

Under the pressure of high fuel oil prices, between 1979 and 1983, ship's engine designers, were challenged to design a more efficient new main engine, focused on its "thermal efficiency". The design of a new main engine emerged as a requirement. The single most important influence on fuel consumption is main engine. A slow steaming policy would have great benefits in terms of reducing carbonization.

In 5 years, between 1979 and 1983, slow-speed, (less than $100 \mathrm{rpm}$ ), marine diesel engines provided higher efficiency in energy conversion: 127 grams per brake horsepower per hour, meaning a 15.3\% improvement. For example, a diesel-powered 300,000 dwt VLCC, (2005 vintage), consumed $68 \mathrm{t} /$ day, at 15 knots, after 1980, meaning a minimum 50\% improvement.

Shipowners, and their engineers, know the relationship between speed, $S_{a}$ and fuel consumption, $F_{a}$, for a diesel engine, following e.g., the formula ${ }^{64}$ :

$$
S_{a}=S_{d} \sqrt[\alpha]{\frac{F_{a}}{F_{d}}},
$$

where $F_{d}$ is the designed fuel consumption, $\alpha$ is a power coefficient, which is 3 for diesel engines, and $S_{d}$ is the design speed. For a steam engine, where $\alpha=2$, and $S_{a}=14$ knots, $S_{d}=16$ knots, $F_{d}=44$ tons, it actually consumes $F_{a}=34$ (rounded) tons per day. The actual fuel consumption is, however, 10 tons/day lower than the design consumption.

As a result, by reducing maximum speed by 2 knots per hour (nearly 4 $\mathrm{km}$./hour), in this example, a ship consumes near 10 tons less fuel per day. And this raises the question of whether an additional 2 knots of speed is worth its additional fuel consumption, and the impact on the environment. At 10 tons per day per ship, for about 28,000 ships, this amounts to $98 \mathrm{~m}$. tons $/$ year ${ }^{65}$ (or $2.41 \%$ of the world's consumption).

\section{Part VII: The History of Fuels Used for Ship Propulsion}

1) Wind as a fuel

The history of ship propulsion is indeed fascinating, as it is related to great advances in technical progress. In the beginning, the power of wind, and the use of sails, provided free energy. Ships then were labour-intensive. This lasted until 1900. The speed of a sailing vessel depended on wind. Often, transit times were important, and thus wind had better to be replaced.

But in 2021, 28,000 existing ships could be equipped with auxiliary wind propulsion technology. The wind (wind turbines), the $\operatorname{sun}^{66}$, and the sea waves are now used for producing electricity along with water through hydroelectric dams.

2) Coal as a fuel

Certain countries found that they had large deposits of coal, and in the early

\footnotetext{
${ }^{64}$ Stopford (2009; p. 234).

${ }^{65}$ The world oil consumption in 2011 was 4059 million tons.

${ }^{66}$ Photovoltaic parks formed in deserts are most productive. Photovoltaic parks are today found at sea and on land, in fields, and in roofs as well.
} 
$19^{\text {th }}$ century -or even today-they produced the coal-powered marine steam engine. At that time, nobody thought of $\mathrm{CO}_{2}$ emissions. Some nations have deposits of lignite, and they use it to produce cheaper electricity (Greece).

3) Gasoline: the only fuel for cars (1890-1900)

Although gasoline came to dominate as the fuel for automobiles, between 1890 and 1900 there was a three-way competition between: a) the steam engine, b) the electric motor and c) the gasoline engine (Brian Arthur, 1994: p. 15). Again, nobody thought of $\mathrm{CO}_{2}$.

Ironically, electric motors reappeared around 2021, to claim their position as the only motive force using clean fuel. Of course, one must also consider how electricity is produced and how it can be made widely available in every prior petrol station.

4) Oil as a marine fuel

Oil dethroned all other fuels, at least partially, and especially reduced the role of coal in producing steam, even though oil was a fossil fuel. Diesel engines also dethroned steam engines. Oil suddenly became very expensive after 1973, and since 1979, and from 2000, and at the end of 2021. Shipowners sought the help of technical progress (Goulielmos et al., 2021). Diesel engines use now as mentioned cheap oil (HFO) - a residual product distilled/cracked from the petroleum process. Fuels today appear also under such acronyms as $\mathrm{VLSFO}^{67}, \mathrm{MDO}^{68}$ and $\mathrm{MGO}^{69}$.

Ships, finally, were equipped with slow speed, 2-stroke, marine diesel engines, burning HFO. Shipowners were happy with the cheap fuel, and the more efficient engine. But all good things come to an end, although shipowners wish to maintain the status quo, using $\mathrm{HFO}$, or something very like it.

5) The world is "waking-up" now to face the climate as an enemy

Almost all nations now, including the EU and USA, by 2021 have woken-up and realized that climate became a real enemy ${ }^{70}$, decided to act intensively. All now want urgent action and dream of a decarbonized future. The Glasgow summit, however, resulted to a compromise, and this paper has revealed that the high cost to restore climate as it was, will prevent governments to do it! It is better to accuse governments for inaction, than to accuse them for economic collapse. Globe has to find smarter and cheaper ways (household independent units producing nuclear power, friendly to humans and the environment) to restore climate among a sufficient growth rate, of say $7 \%$ p.a.

Ships are allowed to use fuel containing up to $0.5 \% \mathrm{~m} / \mathrm{m}$ (mass per mass) sulphur, if they have a scrubber to clean the exhaust gases. A global IMO sulphur limit is in force. Many people believe that this marks the end ${ }^{71}$ of the situation,

\footnotetext{
${ }^{67}$ Fuel oil with very low Sulphur.

${ }^{68}$ Marine diesel oil.

${ }^{69}$ Marine gas oil.

${ }^{70}$ Storms and hurricanes acted uncontrolled in our planet followed by ice melting, which increased sea surface.

${ }^{71}$ This is not the first time when oil has been threatened. In 1980-1990, LNG tankers emerged, and some tankers burned LNG. This saw its demand grow from industries, commercial and domestic users, as cleaner and efficient. Its price, however, rose dramatically at the end of 2021.
} 
when all ships burn the same type of fuel.

6) A mismatch between society's targets and those of the shipping industry

Figure 6 shows the targets of society.

New, proper fuel is required, which can be environmentally sustainable, by 2050.

Figure 7 shows the targets of the shipping industry, and they are somewhat different.

The shipping industry seeks a new fuel, which emits zero carbon dioxide, $\mathrm{CO}_{2}$, and is safe on board. The $\mathrm{CO}_{2}$ emissions from ships worldwide stand at the limits specified in 2012-2018, between $2 \%$ and $3 \%^{72}$. But could a new fuel be available worldwide, in all Ports? Can it be as efficient as HFO? Can it compete with HFO on price? Many dispute this last question.

Shipowners fear a costly new fuel on economic grounds, given the range of new fuels that are being considered. The fuel market is expected to be made up of many small suppliers, and the existing economies of scale may be lost.

Goulielmos $(2005,2018)$ describes self-reinforcing mechanisms in economics. According to this theory, one fuel will prevail, as a result of a small, historical event $t^{3}$. To understand increasing returns, in the case of competing technologies,

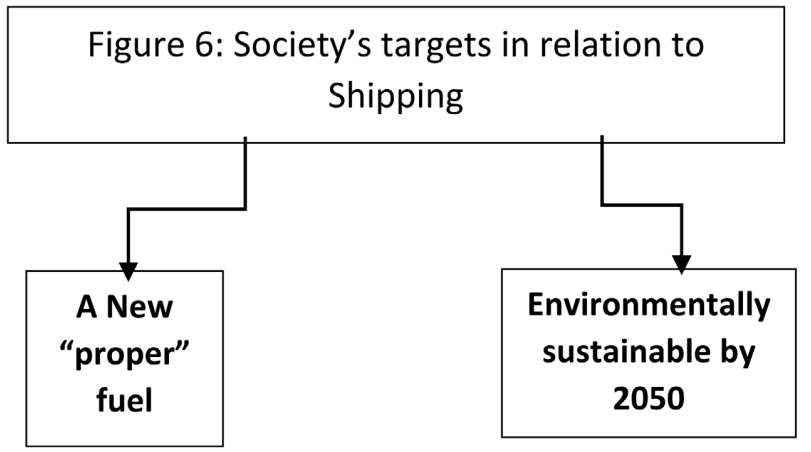

Figure 6. Society's targets in relation to shipping. Source: Author.

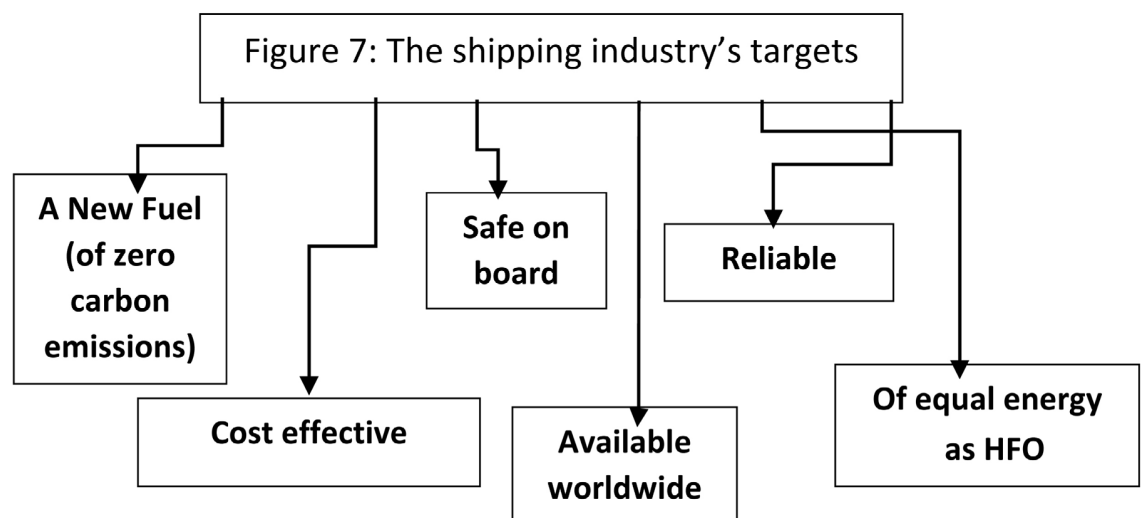

Figure 7. The shipping industry's targets. Source: author.

${ }^{72}$ Bulk carriers and oil tankers, though much greater in number than containerships, had more favorable treatment.

${ }^{73} \mathrm{An}$ event, or condition, outside the knowledge of the observer. 
as here, one has to know that this is a process that is path-dependent, non-ergodic, with many possible outcomes, heterogeneities, small indivisibilities, and chance meetings. These are magnified by positive feedback to tip the system into the actual outcome. History becomes all-important (Brian Arthur, 1994: Chap. 2, p. 27).

\section{Part VIII: The Candidate Fuels for the Future: Advantages and Disadvantages}

1) LNG

Some expect LNG to establish itself as the new ${ }^{74}$ fuel... The expectation is based on the fact that LNG will have an $11 \%$ share of the bunker fuel market by 2030. Four nations would benefit as main producers: USA, Qatar, Australia and Malaysia. In 2018, demand resulted in higher production of LNG in USA. But LNG producers did not understand increasing returns, and as a result, between 1980 and 2000, the LNG bunkering infrastructure did not expand.

The LNG-fueled engines, which exist already in LNG carriers, seem to be efficient and produce lower GHGs emissions (according to Lindstad \& Rialland, 2020). In order for ships to burn LNG, they need an appropriate main engine. Original steam turbine engines must be adapted to be tri-fuel diesel engines (TFDE) and/or a slow-speed diesel engine (MEGI or X-DE).

Whatever fuel is used, high-pressure engines are required anyway. Supporters of LNG propose the "dual-fuel liquefied natural gas (DF-LNG)" engine for LNG carriers, which at the moment is installed in about 500 ships. The advantage of LNG is that it emits $20 \%$ to $25 \%$ less $\mathrm{CO}_{2}$, and is Sulphur free, although it is a fossil fuel, and its liquefaction needs a very low temperature $\left(-173^{\circ} \mathrm{C}\right)$. LNG is composed mainly of methane ( $\mathrm{CH} 4)$. An important obstacle is the limited number of major ports complying with ISO standard 20519/2017 to supply it. LNG suppliers would also have to invest in ports to create supply centers.

Moreover, there is a need to comply with IMO's IGF code for LNG ships, and the compression of natural gas (CNG) for the design and construction of LNG-fueled ships. The lack of trained ratings, and especially officers, is another obstacle.

2) Ammonia (NH3)

A classification society predicted that 30 years from now $25 \%$ of all ships will be powered by ammonia ${ }^{75}$, with zero $\mathrm{CO}_{2}$ emissions if produced by renewable energy sources. Ammonia is bound together with hydrogen bonds in its molecules, which can be converted into electricity in on-site in fuel cells. One strong point in favor of ammonia is the world's first green ammonia terminal ${ }^{76}$, which cost nearly $€ 9$ trillion $^{77}$. Unfortunately, the remaining $75 \%$ of ships are expected to burn still diesel, LPG, HFO and biofuels.

\footnotetext{
${ }^{74}$ Wang (2014).

${ }^{75}$ https://www.offshore-energy.biz/lng-is-no-longer-creating-the buzz-ammonia-is/.

${ }^{76}$ Newsletter@offshore-energy.biz.

${ }^{77}$ Involving Azane fuel solutions \& the Norwegian green platform.
} 


\section{Part IX: The Impact of the Current Energy Crisis}

It is still difficult to estimate the impact of the current energy crisis, and many believe it to be temporary, possibly coming to an end by spring 2022. Others believe that this is the start of a new cold war. We believe that this will be long as Germany investigates the status of the managing company of the Nord Steam 2. But dependence on Russian natural gas varies from a low 3\%, for France, to $100 \%$ for... Lithuania, Estonia, Finland, and Latvia. Germany depends on Russia for $37 \%$ for its gas, and Greece $46 \%$.

Natural gas is priced, in October 2021, at €100/MW/h, due to Russian (Gazprom) policy - a competitor of OPEC. The quantity of gas destined for Europe reduced in order to serve the forthcoming Nord stream 2 pipe line, with 55 billion cubic meters ${ }^{78}$.

The future role of the US shale oil industry in covering part of the gas demand is unknown. Certain other circumstances played a role in the present energy crisis, including the reduction of energy from hydroelectric sources (in Norway, Latin America and elsewhere) due to dry periods, and lack of winds. Nuclear power stations have been closed in the EU. There has been also a post-pandemic consumption rally. And there have been stoppages in Chinese manufacturing as well.

The future price of LNG is also unpredictable given the present international antagonism. It is currently near $\$ 35$ per million British thermal units.

\section{Conclusion}

Shipping industry has to decarbonize its ships ${ }^{79}$ by 2050 . This will need increasingly urgent actions as time goes by, and particularly by 2030, or even earlier. EU-27, in accordance with the forthcoming package, Fit for 55, adopted an initiative, which it is likely to stand by it.

The industry "will"-sooner or later- "design" an efficient main engine, where fuel will follow the engine. The theory of increasing returns requires that once a fuel gains a market advantage, its demand will grow, its average fixed cost will fall, and profits will follow. This is exactly what happened with the car manufacturing in Japan.

Our dream about the world classification societies and the international shipyards is to provide to the shipowners smart ships. But it was more difficult to resolve the dilemma of whether the climate will become a friend, or economic growth will be an enemy. The world's citizens look, with tears in their eyes, at the results of persistent fires, the devastating floods and the unbearable hot summers, all in the time of a pandemic.

Unfortunately, the cost of decarbonization is not clear. The IEA estimated that $4.5 \%$ of the global GDP, or nearly $\$ 4$ tr., are required. Others estimate that $20 \%$ of GDP is required, or $€ 50 \mathrm{~b}$. for Greece alone. Governments will not spend this

\footnotetext{
${ }^{78}$ This was clever as Germany is the leader of EU-27.

${ }^{79}$ Unattainable with existing measures.
} 
amount, we believe. If governments will not meet the challenge, we are left with technology. Technological considerations suggest the use of hydrogen, the increase of the storage capacity of batteries, and the $\mathrm{CO}_{2}$ capture at the point of emission.

High fuel oil prices re-emerged since 2000, and in 2021, when oil may reach $\$ 100$ per barrel. The shipping industry was helped in the past by the manufacturers of marine engines and the major oil companies. The industry was rescued by a new engine and a cheaper fuel (HFO). For 38 years, shipowners were happy with these two tools, until 2005. The IMO terminated their happiness gradually, (by setting emission limits), and by introducing EEDI ${ }^{80}$ (2011). The major shipowners have adopted a uniform position: "wait and see". They are waiting for a new fuel. In the meantime, they stated their demands for the new fuel, which is to be a new green fuel, but an acceptable substitute for HFO.

Our proposal to improve climate is simple, borrowing from the slow steaming policy adopted by ships during maritime crises (1981-1987; 2009-2018). This could produce a reduction of the maximum speed limits for all means of transport. Each $4 \mathrm{~km} / \mathrm{h}$ reduction in ships' speed means a reduction of consumption of $98 \mathrm{~m}$. tons of oil p.a. Our second proposal is for IMO states, classification societies and shipyards to buy and scrap the legally-obsolete ships.

\section{Conflicts of Interest}

The author declares no conflicts of interest regarding the publication of this paper.

\section{References}

Brian Arthur, W. (1994). Increasing Returns and Path Dependence in the Economy. University of Michigan Press. https://doi.org/10.3998/mpub.10029

Bruce, G. J., \& Garrard, I. (1999). The Business of Shipbuilding. LLP Reference Publishing.

Farthing, B., \& Brownrigg, M. (1997). Farthing on International Shipping (3rd ed.). Lloyd's of London Press.

Goulielmos, A. M. (2005). Complexity Theory: A Science Where Historical Accidents Matter. Disaster Prevention and Management, 14, 533-547. https://doi.org/10.1108/09653560510618366

Goulielmos, A. M. (2018). Psychological Economics: The Case-Studies of Eurozone, Global Economic Crisis and Greece. Modern Economy, 9, 1792-1820. https://doi.org/10.4236/me.2018.911113

Goulielmos, A. M. (2018). Self-Reinforcing Mechanisms in Economics: With Two Case-Studies from Shipping Industry. Modern Economy, 9, 1313-1337. https://doi.org/10.4236/me.2018.97085

Goulielmos, A. M. (2021). Scale Economies: An Economic Blessing? Should We Build Still Larger Ships? Modern Economy, 12, 1296-1319. https://doi.org/10.4236/me.2021.128068

Goulielmos, A. M., \& Gatzoli, A. (2012). The Role of a Ship's Master in Theory and Prac-

${ }^{80} \mathrm{EEDI}$ measures for new ships the grams of $\mathrm{CO}_{2}$ per transport work ( $\mathrm{g}$ of $\mathrm{CO}_{2}$ per ton mile). 
tice: Lessons from Marine Accidents. Journal of Critical Incidence Analysis, Fall Volume, 55-78.

Goulielmos, A. M., \& Goulielmos, M. A. (2005). The Accident of the m/v Herald of Free Enterprise: A Failure of the Ship or of Management? Disaster Prevention \& Management, 14, 479-492. https://doi.org/10.1108/09653560510618320

Goulielmos, A. M., Giziakis, C., \& Samprakos, E. (2021). Can We Trace and Estimate the Technical Progress in Shipping Industry by Using the Cobb-Douglas Production Function? Modern Economy, 12, 1563-1592. https://doi.org/10.4236/me.2021.1210079

Goulielmos, A. M., Giziakis, K. V., \& Pasarzis, M. (2002). Should Marine Insurance Companies Take Seriously Chaos Theory? Disaster Prevention \& Management, 11, 312-319. https://doi.org/10.1108/09653560210447008

Keynes, J. M. (1936). The General Theory of Employment Interest and Money. Macmillan \& Co., Ltd.

Lindstad, E., \& Rialland, A. (2020). LNG and Cruise Ships: An Easy Way to Fulfill Regulations-Versus the Need for Reducing GHG Emissions. Sustainability, 12, Article No. 2080. https://doi.org/10.3390/su12052080

Lorange, P. (2009). Shipping Strategy: Innovating for Success. Cambridge University Press.

Metz, K. (2021). Genius Makers: The Mavericks Who Brought AI to Google, Facebook and the World. Random House.

Stopford, M. (2009). Maritime Economics (3rd ed.). Routledge. https://doi.org/10.4324/9780203891742

Taliapetra, S., Volf, G., \& Lenarts, K. (2021). Can Climate Crisis Be Faced without Sacrificing Growth? Sunday Press.

Wang, H. F. (2014). The End of the Era of Heavy Fuel Oil in Maritime Shipping. The International Council on Clean Transportation.

https://theicct.org/blogs/staff/end-era-heavy-fuel-oil-maritime-shipping 


\section{Appendix 1}

The MARPOL 1973/1978/Annex VI ${ }^{81}$ ruled to reduce ships' harmful emissions; this was adopted by the IMO in 1997 and came into force in 2005, except in USA where it came into force in 2009. This was amended in October 2008, and the amendments came into force in 2010. The scope was to limit the emissions of Sulphur $\left(\mathrm{SO}_{\mathrm{x}}\right)$ and nitrogen $\left(\mathrm{NO}_{\mathrm{x}}\right)$ oxides, and particulate matter-PM. Emission control areas (ECAs \& SECAs for Sulphur) were also introduced (Table A1).

Table A1. $\mathrm{NO}_{\mathrm{x}}$ and $\mathrm{SO}_{\mathrm{x}}$ limits (since 2005).

\begin{tabular}{|c|c|c|c|c|c|c|}
\hline Oxide & New Engine & Regulation & Known as & Existing Engine & $\mathrm{NO}_{\mathrm{x}}$ limits & Remarks \\
\hline $\mathrm{NO}_{\mathrm{x}}$ & fuel: diesel & $\begin{array}{l}\text { 13, up to } \\
3.4 \mathrm{~g} / \mathrm{kWh} \\
\text { emissions }\end{array}$ & $\begin{array}{l}\text { Tier III (effective } 2016 \\
\text { in } \mathrm{NO}_{\mathrm{x}} \text { ECAs); } \\
\text { Otherwise Tier II } \\
\text { (effective } 2011 \\
\text { requiring } 14.4 \mathrm{~g} / \mathrm{kWh} \text { ) }\end{array}$ & $\begin{array}{c}\text { Diesel }>5000 \mathrm{~kW} \text {, } \\
\text { of vintages } \\
1990-2000\end{array}$ & $\begin{array}{l}\text { Tier II } \\
\text { Tier I }\end{array}$ & $\begin{array}{l}\text { Tier I: } 17 \mathrm{~g} / \mathrm{kWh} \\
\text { (since } 2000) \\
12 \text { months after } \\
\text { the Administration } \\
\text { notified IMO }\end{array}$ \\
\hline $\mathrm{SO}_{\mathrm{x}}$ & Date & Limit & A new limit & $\mathrm{SO}_{\mathrm{x}}$ & Date & A new limit \\
\hline Global cap & 2012 & $4.5 \%$ & $\begin{array}{c}3.5 \% \mathrm{~m} / \mathrm{m} \\
\text { (mass per mass) }\end{array}$ & & 2020 & $0.5 \%$ \\
\hline In ECAs $\left(^{*}\right)$ & 2010 & $1.5 \%$ & $1 \%$ since 2010 & $\begin{array}{l}0.5 \% \mathrm{~m} / \mathrm{m} \\
\text { since } 2020\end{array}$ & 2015 & $\begin{array}{l}0.1 \% \mathrm{~m} / \mathrm{m} \text {, if such } \\
\text { fuel exists; if not, } \\
\text { goes to } 2025\end{array}$ \\
\hline
\end{tabular}

$\left.{ }^{*}\right)$ ECA: sea area regulated by Paragraphs 13 \& 14 of the revised VI Annex, where mandatory measures prevent, reduce or control ships' air pollution from $\mathrm{SO}_{\mathrm{x}}, \mathrm{PM}$ and $\mathrm{NO}_{\mathrm{x}}$ emissions. Source: MARPOL Annex VI (revised 2008). Scrubbers allow HFO limit $0.5 \% \mathrm{~m} / \mathrm{m}$ of Sulphur. SECAS adopted in N America, North Sea and Baltic (2015).

\section{Appendix 2: The World Consumption of Energy in 2011 (Figure A1)}

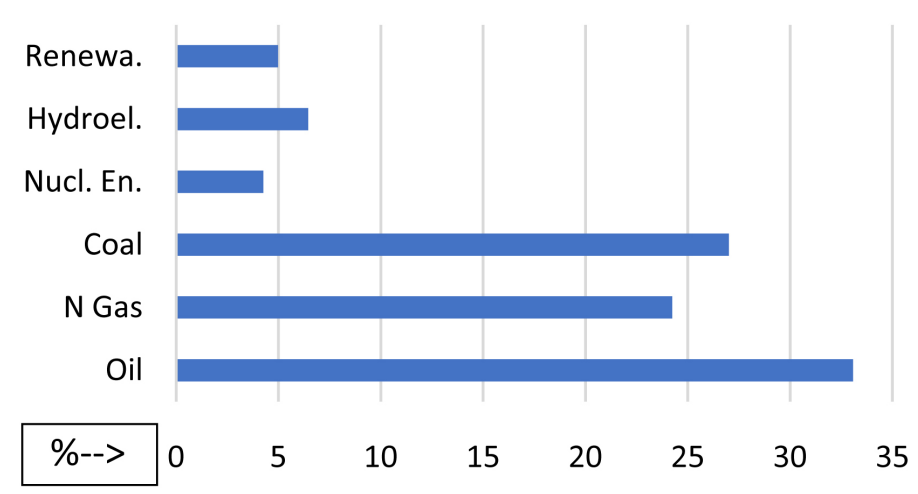

Figure A1. World consumption 2019 (in exajoules). Source: BP statistic tables.

${ }^{81}$ The $1^{\text {st }}$ annex concerned the oil spills caused by tankers due to collision or grounding. Regulation 13F (No 19 now) required the new tankers, ordered after 1993 ( $\left.6^{\text {th }} \mathrm{July}\right)$, to have a double hull. The $13 \mathrm{G}$ (No 20), in 2005, regulation, tried to speed-up the phasing-out of the single hull tankers. Regulation $13 \mathrm{H}$ (No 21), prohibited single hull tankers, over $5000 \mathrm{dwt}$ etc., to carry heavy grades of oil (2006). 
The main fossil fuels, oil and coal, decreased their shares in world consumption from $64 \%$ in 2011 to $60 \%$ in 2019 , due to a steady coal consumption at 158 exajoules $^{82}$. Oil increased from 175 to 193 , an increase of $10 \%$. Natural gas rose from 116 to nearly 141, an increase of around 23\%. Nuclear power fell from 5\% to $4 \%$, as a result of accidents in Ukraine and Japan, and the closing of stations in Germany, and elsewhere, due to political cost. Only Turkey built two additional nuclear power stations with support from the Russians. Hydro-electric and renewables increased from $8.5 \%$ to $11.4 \%$ in 8 years. The long hoped for independence from oil and coal will take a long time. Coal may be dethroned sooner, especially lignite.

\section{Appendix 3: A Catamaran}

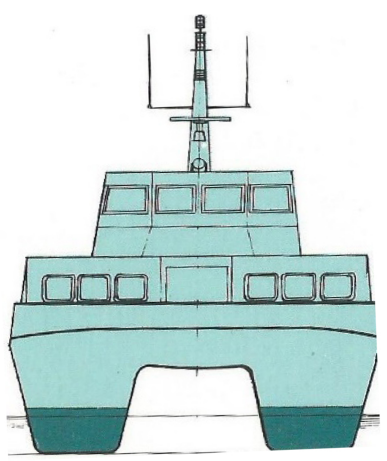

${ }^{82} 1$ joule is the amount of electricity required to run a $1 \mathrm{~W}$ device for 1 second. One exajoule equals $10^{18}$ joules. The USA consumes 94 exajoules per annum. The world needed 584 exajoules in 2019. 